\title{
Spreading of Bio-wastes onto Soil Surfaces to Control Pathogens: Human Health and Environmental Consequences
}

\author{
Zahoor Ahmad $^{1 *}$, Mohamed A.M. Abd-Elbasit ${ }^{2}$, Shahid Javed Butt ${ }^{3}$, Samiullah Khan ${ }^{1}$, Muhammad Liaquat ${ }^{1}$, Ali \\ Raza Gurmani $^{1}$, Abdul Basir ${ }^{4}$, Khair Muhammad Kakar ${ }^{5}$ and Manzoor Qadir ${ }^{6}$ \\ ${ }^{1}$ Department of Agriculture, University of Haripur, Haripur, KPK, Pakistan \\ ${ }^{2}$ Department of Geography, Environmental Management \& Energies Studies, University of Johannesburg, South Africa \\ ${ }^{3}$ Department of Horticulture, PMAS-Arid Agriculture University, Rawalpindi, Pakistan \\ ${ }^{4}$ Department of Agronomy, University of Swabi, Khyber Pakhtunkhwa, Pakistan \\ ${ }^{5}$ Department of Agriculture Extension, Quetta, Pakistan \\ ${ }^{6}$ United Nations University Institute for Water, Environment and Health (UNU-INWEH), Longwood Road South, Suite \\ 204, Hamilton, Ontario, L8P 0A1, Canada \\ *For correspondence: zahoorahmad@uoh.edu.pk; zahoor112@ hotmail.com
}

\begin{abstract}
Thousands of tons of animal and human wastes are produced every day across the globe. Their continuous use as fertilizers or soil amendments on agricultural lands has raised severe health and environmental concerns. Incorporating bio-wastes into the soil is one of the best management strategies to control the run-off of nutrients from the soil surface and, in turn, protect freshwater. However, exposing bio-waste to sunlight in the field is considered to be one of the most cost-effective methods to control pathogens. Considering the differences among different bio-waste management strategies, there is a need for a review of the current knowledge on the practice of spreading bio-wastes onto the soil surface. Specifically, this information would help us to better understand the fate of pathogens upon their exposure to the open environment, how the presence of bio-waste on the soil surface can threaten humans and the environment, and the costs and benefits of surface-applied bio-wastes. Current review of the literature revealed a lack of understanding of the factors responsible for killing pathogens on the soil surface. More than 150 pathogens (including different viruses, bacteria, protozoan and helminth) have been reported to be present in different bio-wastes, but the majority of studies have focused on a few common pathogens. Similarly, over the last decade, each year at least 1 new pathogen is being reported which can threat public health but there is a paucity of knowledge concerning the fate of pathogens under field conditions. Similarly, the techniques used for the detection of pathogens were found to be variable and inconclusive, making it difficult to compare the results of different studies. Therefore, given that the tools for the evaluation of pathogens have serious limitations and the survival characteristics of many (old and emerging) pathogens are yet to be discovered, the spreading of bio-wastes (treated or untreated) onto the soil surface (i.e., unincorporated) may not only further increase the threat for human health but also further aggravate the environment. (C) 2015 Friends Science Publishers
\end{abstract}

Keywords: Pathogens; Bio-solids; Pathogen transport; Surface application; Health risks; Water pollution

\section{Introduction}

Summing the annual amounts of municipal solid waste (2 Billion Metric Ton; BMT), sewage sludge (0.7 BMT), construction and demolition waste (1.42 BMT), industrial waste $(1.42 \mathrm{BMT})$, and the 3 different types of agricultural/forestry wastes (i.e. animal, plant, and forestry residues) (30.51 BMT) results in 35.5 BMT of global waste per year (Marxsen, 2001). One recent global estimate also showed that only municipal waste and industrial waste generation is mounting between 3.4 and 4 billion tones and predicted to increase further in future (Chalmin and
Gaillochet, 2009). Although most of the waste is recycled, incinerated, used as fuel (in developing countries), or deposited in landfill sites, a significant amount of agricultural wastes and bio-solids make their way onto agricultural lands as fertilizers or soil amendments. Sheldrick et al. (2003) estimated that globally about 34 million tones of nitrogen and 8.8 million tones of phosphorus nutrients could be recovered as manure applied on agricultural lands.

Application of bio-wastes to soil has raised severe concerns about environmental pollution globally. It has been estimated that manures application causes the addition of

To cite this paper: Ahmad, Z., M.A.M. Abd-Elbasit, S.J. Butt, S. Khan, M. Liaquat, A.R. Gurmani, A. Basir, K.M. Kakar and M. Qadir, 2015. Spreading of bio-wastes onto soil surfaces to control pathogens: human health and environmental consequences. Int. J. Agric. Biol., 17: 671-680 
8.3 million tones of nitrogen and 1.5 million tones of phosphorus into freshwater bodies globally each year (FAO, 2006). Only about half of the applied fertilizer is actually taken up by crops (Bøckman et al., 1990), and there is marked economic losses and environmental implications. Spread of microorganisms is one of the problems, which might cause diseases to humans and animals. Pathogens may persist in all form of bio-wastes collected on farms, in addition to human wastes. Bio-waste is present in different forms such as solids, semi-solids (slurry), or liquids (waste water) and is incorporated into soil, spread onto soil, sprayed onto the soil surface, or injected into the soil (US EPA, 2011). Currently in the UK, it is a common practice to leave the manure on the soil unincorporated for a period of at least 1 week before incorporation (Hutchison et al., 2004), while the slurries are either spread on the soil surface or injected into the soil (Nicholson et al., 2005). According to Nicholson et al. (2004), in the UK more than $90 \%$ of slurry is spread over the land and about $50 \%$ of fresh manure is directly applied to the lands. In the case of pastureland, incorporation of manures and slurries is a difficult task, therefore, they are applied to the soil surface (NRC, 2002). While there is no trend of incorporation of bio-wastes in forests (US EPA, 2011). From an agronomic point of view, bio-wastes are also left on the surface unincorporated for the sake of zero tillage (Mkhabela et al., 2008). These practices are preferred because of their ease in terms of handling, they are economic ways of disposal, or because of a lack of available storage space on the farm. Similarly, when considering pathogens, it has been recommended to delay the incorporation of wastes such that the pathogen numbers are reduced due to exposure to UV rays and/or increased temperatures from sunlight (NRC, 2002; Hutchison et al., 2004; Forslund et al., 2011).

From an environmental point of view, immediate incorporation of bio-waste into the soil surface is one of the best waste management practices (Webb et al., 2010). Studies have shown that leaving the wastes on the soil surface will rather enhance the chance of nutrient, as well as pathogen, escaping from the soil surface (Heinonen-Tanski and Uusi-Kämppä, 2001; Daverede et al., 2004; Ramosa et al., 2006; Uusi-Kämppä and Heinonen-Tanskib, 2008; Venglovsky, 2009). Quinton et al. (2003) reported that the surface application of bio-waste may enhance the transport of pathogens from the soil, and they observed a significantly higher transport of pathogens (fecal coliforms) from plots in which slurry was applied to surface when compared with plots in which slurry was mixed into the soil. Study of Bradford and Schijven (2002) concluded that the manure present on the soil surface may act as a long-term source of pathogen contamination. According to Heinonen-Tanski and Uusi-Kämppä (2001) spreading of slurry increases the microbial levels in runoff waters which can be protected if slurry is injected into soil. Uusi-Kämppä and HeinonenTanski (2008) also reported a higher runoff of nutrients and microorganisms following the surface application of slurry.
Since different bio-waste application strategies (immediate incorporation or delayed incorporation in soil) have different implications in terms of human health and nutrient run-off from the soil, one waste management practice can contradict another. In the greater interest of human health and sustainable agriculture, the question of whether spreading different bio-wastes onto the soil surface unincorporated is a sustainable practice, is gaining immense importance as a result of increasing reports of food-/waterborne disease outbreaks and the rapidly changing environment. Therefore, in the light of the available knowledge, there was a need to re-evaluate the practices that involve the spreading of bio-wastes onto the soil surface such that new guidelines can be produced for the safe disposal of bio-wastes in the broader context of human health and the environment.

\section{Risks Associated with the Spreading of Bio-wastes onto the Soil Surface}

Both the environment (with respect to nutrient pollution and the emission of greenhouse gasses from bio-wastes) and pathogens ultimately pose risk to human health. The risk of nitrogen loss in the air and water pollution by chemicals are indirect and gradual and, in most cases, the effects are not seen over a short period of time. However, the risks posed by pathogens present in different bio-wastes on human health have relatively quicker and obvious effects in most cases. In this scenario, the judgment seems largely true that waste management guidelines are mainly focused to control chemical pollution from wastes, which overshadow the risk of the dissemination of bacterial pathogens from these pollutants (Hutchison et al., 2004).

Bio-wastes, including human and animal wastes, contain a huge number of microorganisms that may act as pathogens. Most of the major pathogens present in human and animal wastes are common between different types of waste but there may be differences at the level of the strain. According to a British survey, a sample of livestock waste may contain Campylobacter, Giardia, Salmonella, Listeria, Cryptosporidium parvum or Escherichia coli $\mathrm{O} 157$ at mean levels of up to $106 \mathrm{~g}$ per waste (Hutchison et al., 2002 reported by Hutchison et al., 2004). Therefore, just after bio-waste is spread onto agricultural land and before the surface environment is able to have any effect of reducing the numbers of pathogens, bio-waste-associated pathogens applied to orchards or agricultural fields may enter the food chain. Though the number of viable cells necessary to cause disease varies considerably between the species, however, bacterial presence in large numbers is not a prerequisite for illness. Some strains of pathogens (for example, $S$. typhimurium) are very infectious, event ingestion of fewer than ten cells may cause sickness in susceptible person (Kothary and Babu, 2001). Therefore, surface-applied biowastes have been reported to cause serious consequences for the vege like sprouts which are ready to eat (Guan and 
Holley, 2003).

Similarly, juice or cider made from windfall apples might have been contaminated by manure of either cattle or deer, both carriers of $E$. coli O157:H7 (Smith, 2010). Since 1992, several vege-associated outbreaks were found to have been related to the growing of produce in soil layered with manure (Kudva et al., 1998; Vernozy-Rozand and Roze, 2003). Leafy vegetables (alfalfa and sprouts) and root crops (radishes and carrots) which directly touch the soil, also poses sever threat to human health (Breuer et al., 2001).

Pathogens from the soil may escape through vertical or horizontal transport (Venglovsky et al., 2009) well before any interactions with the soil surface environment occur. There are a number of factors which may affect the transport of the microorganisms (e.g. soil properties, pathogen type, land cover, and weather). However, the form in which the waste material is applied to the soil surface (i.e. solid, slurry, or waste water) can certainly have important implications in terms of both horizontal (surface or subsurface runoff) and vertical movement. For example, some time application of dry bio-solids on soil surface may produce higher bioaerosol emissions compared to the liquid bio-solids (Paez-Rubio et al., 2007).

Pathogens present in surface-applied bio-solids may get transferred to the surface of water bodies via rain or irrigation water. In contrast with chemical contaminants, microorganisms are suspended, rather than dissolved in water therefore, the mode by which they are transported vertically will be slightly different than that for chemicals. Organic compounds present in different types of waste are able to compete with viruses for adsorptive sites on soil colloids. Considering the capacity of microorganisms to bind to organic substances, the transport of pathogens applied onto the soil surface might be more associated with organic matter than with soil sediments (Ramosa et al., 2006). Attachment of pathogenic to negatively charged soil/sediments/rocks is not facilitated because most of the microorganisms have a low net negative surface charge over a wide range of soil $\mathrm{pH}$. However, presence of positively charged inorganic surfaces in soil encourages microorganisms and protozoa oocysts through peculiar chemical interactions (Pachepsky et al., 2006). For instance, glycoproteins are present in the outer walls of $C$. parvum oocysts which help oocysts to adhere with inorganic surfaces in soil (Kuczynska et al., 2005). Similarly, bacteria frequently secrete extracellular polymeric materials which help them to keep them attached with particle surface. However, the application of manure to the soil surface might slow the adsorption of viruses (Shelton et al., 2003), which would ultimately affect their mobility.

The size of the individual pathogen or its floc may also play an important role in its vertical movement from the top soil to the underground water or the sub-surface runoff. The size of soil pores and soil biota varies greatly, as shown in Fig. 1, which may facilitate or hinder the movement of microorganisms. Size of virus is in the range of nanometers,

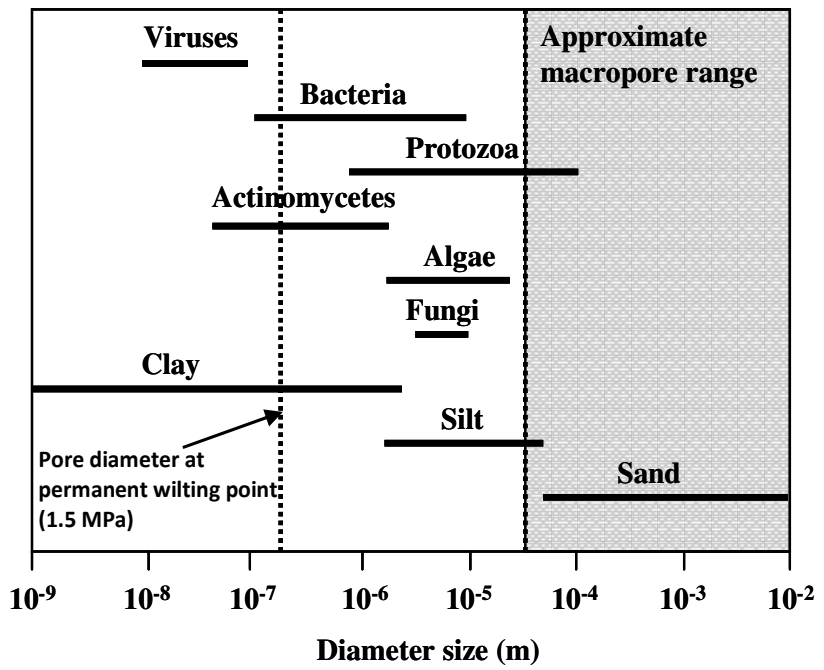

Fig. 1: Size ranges of soil particles and pores, and of microorganisms. The vertical broken lines represent the equivalent diameters of pores, which empty at permanent wilting point (PWP), and at the transition between micropores and macropores (Source: Buchan and Flury, 2004)

bacteria in micrometers, while protozoa is in the range of micrometers to hundreds of micrometers (Buchan and Flury, 2004). Pathogens may form large cluster due to the bacteria clumping or by formating virus aggregates. Their transport will be influenced by the size of the other members of the population, which will be limited by the size of pore spaces. Movement of pathogens is facilitate by the presence of pores which provides preferential water flow and hinders if the soil is compact (Artz et al., 2005). Microbes can even move quicker through the soil pores than the mean pore-water velocity (Buchan and Flury, 2004). Salmonella has been detected from a depth of $2 \mathrm{~m}$ in pasture and $8 \mathrm{~m}$ from the soil contaminated with pig slurry. Similarly, Pachepsky et al. (2006) reported that bacteria may move through surface/subsurface water flow and ultimately reach fresh water resources.

The degree of water saturation is a major factor controlling microbial activity in the soil and the transport of microorganisms through the soil. Bacteria are transported over much greater distances in saturated soils, and the general lack of movement and limited survival of pathogens in the soil is associated with unsaturated conditions (Bitton and Harvey, 1992). Some microorganisms (bacteria) have special patterns of cell motility, for example, the ability to move using the viscous drag in water in search of more favorable conditions (Berg, 2000). The main transport mechanism is passive convection with the local flow of the soil solution. However, Buchan and Flury (2004) also observed active movement in some microbe, for example via chemotaxis i.e. a movement along a chemical gradient such as toward a food substrate. The ability of pathogens to 
move in search of food and water may help them move from the soil surface into the soil. In terms of vertical movement, the dissolution of solid wastes on the soil surface is very important to release the pathogens and nutrients present. The mechanism by which pathogens are released from wastes applied onto the soil surface is poorly documented in literature. The majority of studies on the transport of pathogenic bacteria in soils used bacterial cells that were suspended in solution and then applied to the soil surface or mixed with the influent solution. The results of those studies are only partially applicable to microbial leaching from either land-applied or naturally deposited solid manures, since microorganisms must first be released from the solid manure matrix before they can infiltrate into, and leach through, the soil profile (Shelton et al., 2003).

\section{Interaction of the Soil Surface with Pathogenic Communities}

Leaving bio-wastes on surface unincorporated is considered as a mean to expose pathogens to adverse environmental factors that are lethal for their growth and survival (NRC, 2002; Hutchison et al., 2004; Forslund et al., 2011). The environmental factors that interact with pathogens on the soil surface are sunlight (UV light), drying, freezing and thawing cycles, high temperatures, exposure to oxygen, and ammonia. The direct thermal inactivation of microbus by solarization process is important process under which soil temperature is raised to a level which is lethal for most of the microorganisms. The amount of soil moisture is also an important variable but the inactivation of pathogens also depends on the soil and air temperatures. The soil temperature during solarization itself depends on factors like air temperature, soil structure, soil color, and day length (i.e. time of exposure to sunlight) (DeVay and Katan, 1991). Determining the relationship between the soil temperature during solarization and the rate at which the process kills a given pathogen is a complicated task. The time course and pattern of heating during soil solarization is very different from that usually established based on heat mortality curves generated under controlled laboratory conditions (Streck et al., 1996). It has been reported that more than 150 microbial pathogens from animals can be transmitted to humans through different routes (USDA, 1992; US EPA, 1998) and they greatly vary in terms of their resistance to temperature under different environmental conditions. For any group of organisms, only a few species are able to survive close to the upper temperature limit for the group; most organisms in the group live only at lower temperatures. For example, the upper limit for vascular plants is about $45^{\circ} \mathrm{C}$, fungi $60^{\circ} \mathrm{C}$, and bacteria 70 to $>100^{\circ} \mathrm{C}$. Giardia cysts were reported to be non-infective after $7 \mathrm{~d}$ at $-4^{\circ} \mathrm{C}$ in soil, while Cryptosporidium survive for more than 12 weeks (Olson et al., 1999). After one week Giardia cysts were inactivated in soil while Cryptosporidium oocysts survived at $25^{\circ} \mathrm{C}$. In cold soil $\left(4-6^{\circ} \mathrm{C}\right)$, most of the pathogens survived for at least
30 days and Helminths were the most persistent of the enteric pathogens. According to Varadyova et al. (2001) Ascaris eggs are viable for many years in soil, extreme weather i.e. very dry or wet weather effects the viability. Among all the pathogens, the greatest survival was observed for E. coli O157:H7 and Salmonella in warm (20-30 C) soil and Cryptosporidium in frozen soil. Most of the bacterial pathogens could not survive in the temperatures higher than $60^{\circ} \mathrm{C}$ (Rosen, 2000). However, bacteria which produces resistant endospores or have thick-walled cells, are more resistant to temperature well near to $100^{\circ} \mathrm{C}$ (Kelly, 1978).

The exposure of bio-wastes on the soil surface to achieve the thermal reduction of pathogens may reduce some of the pathogens, but the risks to human health may still persist. For instance, Hutchison et al. (2005) observed that $C$. parvum took about 8-31 days for a $1 \log$ reduction when left unincorporated on the top of the pasture, and protozoans were significantly hardier as compare to the bacteria.

Solar irradiation is another factor that interacts with different pathogenic communities on the soil surface. It has been identified that UV-B (290-320 nm), UV-A (320-400 $\mathrm{nm})$, and blue to green visible light $(400-550 \mathrm{~nm})$ of the solar spectrum are responsible for inactivating indicator microorganisms, but the UV-B portion of the solar spectrum is the dominating bactericide causing direct (photobiological) DNA damage (Yukselen et al., 2003; Alonso1 et al., 2005). There is general agreement that DNA is a principal target of UV rays. However, main mechanism of inactivation of microorganisms is not crystal clear. For instance, in case of coliforms, photochemical mechanisms become more important at wavelengths above $329 \mathrm{~nm}$, where it acts through photosensitizers to damage the cell membrane (Sinton et al., 1999). The execution of solarization appears to be a simple process but its overall mechanism is very complicated which involves a number interrelated reactions and processes (Stapleton, 2000). Sunrays might be lethal for many microorganisms, but some forms of pathogens are resistant to even extreme artificial UV irradiation, for example, Giardia cysts owing to their thick outer layer. Some mechanisms are direct, for example, the heat inactivation of cellular processes, while others are indirect, involving weakening of cells and increasing their sensitivity to antagonistic microorganisms as well as to pesticides and other abiotic stresses present in the soil environment. The mechanisms are complex, and the interactions of different factors are not fully understood (DeVay and Katan, 1991). Field studies that have reported the reduction of pathogens on the surface (Hutchison et al., 2004; Hutchison et al., 2005; Nicholson et al., 2005) have some serious limitations. Most importantly, while counting the number of pathogens on the soil surface, pathogens that might have been transferred from outside the system with leaching or runoff water as a result of rainfall events were not considered. In contrast, some reports have shown that pathogens may survive better if bio-wastes are applied on 
the surface rather than injected into the soil. Avery et al. (2004) reported that in the surface application of waste (both slurry and solid), E. coli $\mathrm{O} 157: \mathrm{H} 7$ was detected until 4 weeks after the application, suggesting that the risk of pathogen could be reduced by sub-surface injection of biowastes. They also observed that after the grass was cut at 42 days, number of pathogen cells increased slightly under all treatment combinations. Similarly, the data of Nicholson et al. (2005) shows that pathogens survive better in wastes applied to the surface of a grassland soil than in wastes mixed into the top of an arable soil. Pathogens may survive for months, even for years, in pastures where they can escape from UV radiation (Jones, 1986). Solar radiation, alone or in combination with other methods, has been used successfully for the disinfection of greenhouse soils or seed beds from weeds, plant pathogens, or insects under controlled conditions (Ioannou, 2000; Lira-Saldivar et al., 2004). Sunlight has also been used in field conditions but under plastic mulches (Miyasaka et al., 2001). Such protected practices might be more useful for controlling pathogens under field conditions.

The form in which bio-waste is applied (solid, semisolid, or liquid) may also influence the survival of pathogens on the soil surface. How shift of solid waste management system to liquid waste management system will affect the survival of pathogens is still not clear (Hutchison et al., 2005), but generally, it is assumed that pathogens survive better in slurry or wastewater than in dry bio-wastes. In the field of animal husbandry, during the last 3 decades, solid waste management system is slowly replaced by slurrybased management systems (Strauch and Ballarini, 1994), implying that the likelihood of pathogen survival and spread would further increase. Contrary to the situation for dry biosolids, liquid manures (slurry or wastewater) applied to the surface have different consequences with respect to the survival of pathogens in soil. Pathogens present in semisolids/slurry may escape the soil surface to a s subsurface environment through leaching. According to Niewolak (1994) microorganisms (Escherichia and Salmonella) from pig slurry can penetrate $160-180 \mathrm{~cm}$ into soil. Henry et al. (1995) isolated Salmonella from a depth of $2 \mathrm{~m}$ in pasture and $8 \mathrm{~m}$ in soil after the application of contaminated pig slurry. Hutchison et al. (2005) inoculated different waste types (including solids, slurry, and waste water) with $L$. Monocytogenes, Salmonella, E. coli O157, C. jejuni, and C. parvum oocysts and observed that the levels of most of the pathogens decreased to below the detection limit after 64 days, while $L$. monocytogenes took 128 days to decline. Bolton et al. (1999) observed that the number of E. coli decanted onto grassland decreased by $4.0-5.0 \log _{10}$ colony forming units (CFU) per gram in 50 days, but cells were still detec in the surrounding soil even after 99 days. Therefore, the longer survival of pathogens in the grassy environment increases the chances that other animals, birds, or humans might be infected or re-infected during grazing or after harvesting and ensiling.
Overall, a number of factors affect different pathogens, and these are so complex that it is quite difficult to predict the exact environmental conditions that may favor or limit the survival of these organisms on the soil surface.

\section{Risk of Pathogen Spread from Pretreated Bio-wastes}

Bio-wastes are either applied onto the soil surface as collected (fresh) or after some degree of pretreatment. In United States sewage sludge has to be treated with processes that enable a significant reduction (Class A), or further reduction (Class B), of pathogens before it is applied to land as bio-solids (40 CFR, Part 503). Application of Class B treated sludge is also associated with access, grazing, and/or crop harvesting restrictions and a vector-attraction reduction process. Class A materials are assumed to be essentially pathogen free and its land application is not subjected to any access, grazing, or harvesting restrictions. Although the US Environmental Protection Agency (1993) gave some additional guidelines for the use of bio-solids to restrict the possible health hazards of pathogens, health risks associated with the surface application (unincorporation) of bio-solids were not taken into account; rather federal rules allow the application of sludge onto the surface without being incorporating into the soil (Harrison and Oakes, 2002). In an investigation, Harrison and Oakes (2002) observed that the main source of illnesses in the area was the surface application (un-incorporation) of Class B bio-solids. This report suggested that the use of Class $\mathrm{B}$ sludge on agricultural land should be eliminated. According to one estimate about there is one human pathogenic bacterium per 1000 coliform bacteria in sludge and one human enteric virus in Class B sludge per 1000 coliphage (Tanner et al., 2005). On the other hand, Class A bio-solids, which are supposed to contain pathogen levels within certain limits or below the detection level may also pose a threat to human health. These safety criteria are not related to the potential of microorganisms in bio-solids to re-grow (Zaleski, 2005a; Alkan and Topaç, 2007). Re-growth of pathogens has been reported in both Class A and Class B bio-solids under the field and storage conditions (Zaleski, 2005a; Alkan and Topaç, 2007). Zaleski et al. (2005b) discussed in detail the survival, growth, and re-growth of pathogens present in biowastes.

Fecal coliform is an important indicating to declare the bio-solids of Class A, while under specific temperature conditions, enteric viruses, Salmonella spp. and helminth ova are not required to monitor. However, absence of one, two or three indicator does not ensure that bio-solid is free of pathogens (Sidhu and Toze, 2009). Recently, Arthurson (2008) reviewed the existing waste treatment procedures, and identified flaws in the standard procedures in eliminating pathogens from sewage sludge. Some researchers have suggested that current division of biosolids into different classes like Class A \& B should be replaced with only one best standard class (Gattie and 
Lewis, 2004). In addition to variation in the treatment method, the composition of sludge generated from different geographical locations and individual treatment facilities also varies appreciably. The differences in bacterial communities are due to both spatial and temporal factors such as seasonal variation (Placha, 2001). Consequently, sludge from a single specific wastewater treatment work cannot be approved for arable land application based on the microbial quality assessment on isolated occasions (Arthurson, 2008).

Unlike the case of bio-solids, pathogens count in manures is not as strictly regulated as in sewage sludge. Manures are even greater sources of pathogens than human wastes because masses of manure applied are greater than the sewage sludge (Moss et al., 2002). Most of the farmers spread manure directly onto their land, either because of lack of storage space or for greater convenience (Smith $e t$ al., 2000; Smith et al., 2001). Application of fresh manure onto agricultural land significantly increases the risk of microorganisms transfer to food chain, because temporary storage may help to decrease the number of pathogens (Nicholson et al., 2005). According to USEPA (United State Environmental Protection Agency), for static manure piles, a minimum temperature of $55^{\circ} \mathrm{C}$ should be maintained for 3 days, while temperatures greater than $55^{\circ} \mathrm{C}$ should be maintained for at least 15 days in case of windrows (US EPA, 1999). However, observation of these composting guidelines does not guaranty the complete elimination of pathogens. Similar to those used for sewage sludge, treatment processes used for manure have been questioned for their ability to reduce pathogen numbers (Haapapuro $e t$ al., 1997; Kudva et al., 1998; Nicholson et al., 2005). For example, it has been reported that deep stacking is unable to eliminate some pathogens due to the low temperature attained during the treatment (Haapapuro et al., 1997). Kudva et al. (1998) reported that E. coli O157:H7 could be detected after 47 days in bovine manure, 4 months in aerated ovine manure and 21 months in non-aerated ovine manure. Even within a given lot, there was a high degree of variation in several characteristics. Manures significantly differ in their compositions which ultimately affect pathogen populations (Ioannou, 2000) and chances of pathogen survival is higher in the cooler exterior or drier parts of the manure heap (Nicholson et al., 2005). Wichuk and McCartney (2007) conducted a detailed review in which they discussed the interaction of composting time and temperature on pathogen activities.

Like other wastes, effluents are not exceptional; effluents also carry microorganisms to fresh surface water resources. Wastewater is either applied to recharge ground water or applied to lands as a method of further treatment. Generally, pathogens inactivation is slower in manure slurries than the manure heaps (Nicholson et al., 2005) mainly due to the high temperatures within the manure heap. Reports have shown that treated wastewater may carry one viable intestinal nematode egg per liter for restricted or non-restricted irrigation, and less than thousand fecal coliform bacteria per hundred milliliter for unrestricted irrigation (Blumenthal et al., 2000). Even tertiary-treated reclaimed wastewater has been shown to contain viable Cryptosporidium oocysts (Quintero-Betancourt et al., 2003). Similarly, some reports indicated that even mineral water may be contaminated with Norwalk-like viruses (Beuret et al., 2002), thereby raising questions on the technologies being used at water treatment plants for detection and disinfection.

Concerns over the ability of available laboratory techniques to detect pathogens in waste have been raised by many researchers (Mawdsley et al., 1995; Regueiras et al., 2009; Sidhu and Toze, 2009). According to Sidhu and Toze (2009), current analytical techniques are not competent enough to detect the pathogen numbers and survival in biosolids. Low counts of pathogenic microorganisms in any treatment plant may result in the disposal of wastes onto the soil surface for one reason or another. Under harsh environment, many pathogens are reported to become more resistant and transform themselves into a viable but nonculturable (VBNC) state retaining all their pathogenicity and do not grow on conventional growth media (Bjergbaek and Rosley, 2005; Colwell, 2009). Microorganisms like Campylobacter jejuni, Vibrio cholera, E. coli and Salmonella spp. can easily enter into viable but noncultureable state under unfavorable environmental conditions like surface/ground water, seawater or salted food (Mattick et al., 2000; Makino et al., 2000; Khan et al., 2007). Upon recovery from the starvation survival state, cell division starts again (Colwell, 2009). Most of the pathogens when are in VBNC state are not detec in conventional analytical methods (Rezzonico et al., 2003; Buck and Oliver, 2010) and can be easily overlooked in conventional techniques of analysis (Panutdaporn et al., 2006). There is need of further knowledge and understanding about the pathogens survival in bio-wastes and their re-growth pattern in treated bio-wastes applied on soil surface (Venglovsky et al., 2009).

A lot of research is being carried out to quantify the pathogen population and indicator organisms in bio-wastes but due to the lack of standardized methods used for these analyses, results are quite difficult to compare (Sidhu and Toze, 2009). Variation in the different sampling and testing procedures greatly restricts comparisons of the results of the different studies (Bolton et al., 1999), which impacts our understanding of the growth and survival of pathogens under different conditions.

\section{Climate Change and New Emerging Pathogens}

A global climate change may directly or indirectly affect the transmission of agricultural contaminants into the food chain or directly into humans. This change in climate may increase the frequency and intensity of rainfall events (Boxall et al., 2009); therefore, the transport of pathogens 
and nutrients from the soil from unincorporated bio-waste may increase. The global surface temperature has increased by about $0.3-0.6^{\circ} \mathrm{C}$ during the twentieth century (Zell, 2004). As warm air can hold more moisture than cold air, the global hydrological cycle has also changed due to the surge in global temperature, as has the prevalence of waterborne disease vectors (Patz et al., 2000). According to Boxall et al. (2009), increase in global temperatures could introduce new pathogens, vectors, or hosts which are not know earlier and require new management strategies. Boxall et al. (2009) reviewed the impacts of global climate change on the indirect exposure of humans to pathogens and chemicals from agriculture. Change in climate may also lead to changes in current farming practices. For example, increased temperature will force the housing of animals indoors. Studies have shown that this confined animal rearing is an important reservoir of pathogens (Gerba and Smith, 2005), which may spread horizontally to other animals or farm workers (Costantini et al., 2007). Confined animal operations also encourage the application of antimicrobials, resulting in the evolution of microorganisms which are more resistant and may survive in the new environment (Cole et al., 2000).

In addition to known pathogens, new pathogens are discovered every year, and our understanding about their survival in different environments and under different control strategies is unknown (US EPA, 2011). According to the World Health Organization (WHO, 2003), each year at least one new pathogen is being discovered which can threat human health. Skovgaard (Skovgaard, 2007) reviewed the trends in new emerging pathogens in the food chain. Discovery of new pathogens is mainly due to the refinement in analytical procedures over the last two decades (Harrus and Baneth, 2005). As analytical protocols are being developed, presence of enteric pathogens in biowastes is judged through the presence of few indicators (Sidhu and Toze, 2009). As a result, many questions regarding the potential public health risks, from the application of bio-wastes to land, remain unanswered (Pirchner, 2007 reported in Sidhu and Toze, 2009). Only full understandings about the all pathogens will help us to device new best management practices that will ensure food safety and prevent spreading of pathogenic diseases (Venglovsky et al., 2009). Overall, our perception and understanding about the potential public health risks of different bio-wastes will improve with the invent of new effective diagnostic tools.

\section{Conclusion}

Health and environmental hazards associated with the spreading of different bio-wastes on the soil surface were assessed in the light of the available knowledge. Exposing the bio-waste to sunlight in the field was considered to be one of the most cost-effective methods for controlling pathogens. Laboratory studies have shown that pathogens are sensitive to temperature, moisture, and UV light, which could have the effect of disinfecting the bio-wastes on the soil surface. However, there is a severe lack of extensive field studies that can confirm the laboratory outcomes. Most of the field studies that reported a reduction in pathogens as a result of the un-incorporation of wastes into the soil were found to have serious flaws, in particular, they did not consider pathogens that were dislocated (horizontally or vertically) from the experimental setup due to irrigation or heavy rainfall. More than 150 pathogens have been reported to be present in different bio-wastes, while most studies have focused on only a few major pathogens. The current knowledge about the effects of environmental exposure on many other pathogens is severely lacking (US EPA, 2011). A review of the literature revealed that the treatment methods used to disinfect bio-wastes are not fully capable of removing the pathogens that might create risks for humans and animals under field conditions. Techniques used in the laboratory to detect the pathogenic agents are still under development, which has lead to the discovery of new pathogens every year. Un-incorporation or delayed incorporation of bio-waste, for one or other reason, may cause the spread of pathogens and pose threat to environment.

Pathogen control can be better achieved through intensive onsite (waste treatment plants) or on-farm treatment before the contaminated wastes reach the soil surface and are exposed to the environment. Nutrient control cannot be carried out through onsite treatment until the wastes reach the field; therefore, filed management practices should be focused only on nutrient management. On the other hand, as time passes, waste production is increasing, technological development is focusing more on the economy, and farmers are increasingly tending toward the easiest and most effective tools for waste management. The use of nature (i.e., light and heat) with minimum additional cost will be one of the options to meet the demands of producers and users. Natural resources can be utilized by the careful adoption of strategies that give full use of natural resources (light and heat) without jeopardizing human health and the environment. For instance, in Germany, all sewage treatment plants have been equipped with UV treatment to achieve the required water quality levels (Pirchner, 2007 reported by Schultz-Fademrecht et al., 2008). Alkan and Topaç (2007) also reported that additional solar heat helped in inactivating bacteria effectively from a covered sludge drying bed than open drying bed, and these also offered better protection against the re-growth of bacteria. Similarly, storage or waste stabilization ponds can be exposed to sunlight for the inactivation of different pathogens (Davis-Colley et al., 1999; Craggs et al., 2004), and it is well recognized that if the waste stabilization ponds are designed for sunlight exposure are more effective than those that do not (Mayo, 1995). The use of such integrated technologies will be very helpful in protecting human health and the environment. 


\section{Acknowledgement}

Cooperation of Professor Mitsuhiro Inoue, Arid Land Research Center, during this study greatly acknowledged.

\section{References}

Alkan, U. and F.O. Topaç, 2007. Birden B, Baskaya HS. Bacterial regrowth potential in alkaline sludges from open-sun and covered sludge drying beds. Environ. Technol. 28: 1111-1118

Alonso1, E., A. Santos and P. Riesco 2005. UV disinfection: Radiation and wastewater quality parameters as operational indicators. Fresen. Environ. Bull., 14: 322-326

Arthurson, V., 2008. Proper hygienization of sewage sludge - a critical issue for a sustainable society. Appl. Environ. Microbiol., 74: $5267-5275$

Artz, R.R., J. Townend, K. Brown, W. Towers and K. Killham, 2005. Soil macropores and compaction control the leaching potential of Escherichia coli O157:H7. Environ. Microbiol., 7: 241-248

Avery, L.M., P. Hillb, K. Killhamc and D.L. Jones, 2004. Escherichia coli O157 survival following the surface and sub-surface application of human pathogen contaminated organic waste to soil. Soil Biol. Biochem., 36: 2101-2103

Berg, H.C., 2000. Motile behavior of bacteria. Physics Today, 53: 24-29

Beuret, C., D. Kohler, A. Baumgartner and T.M. Lüthi, 2002. Norwalk-like virus sequences in mineral waters: one-year monitoring of three brands. Appl. Environ. Microbiol., 68: 1925-1931

Bitton, G. and R.W. Harvey 1992. Transport of pathogens through soils and aquifers. In: Environmental Microbiology, pp: 103-124. Mitchell, R. (ed.). Wiley-Liss, New York, USA

Bjergbaek, L.A. and P. Rosley, 2005. Formation of non-culturable Escherichia coli in drinking water. J. Appl. Microbiol., 99: 1090-1098

Blumenthal, U.J., D.D. Mara, A. Peasey, G. Ruiz-Palacios and R. Stott 2000. Guidelines for the microbiological quality of treated wastewater used in agriculture: Recommendations for revising WHO guidelines. Bull. World Health Org., 78: 1104-1116

Bøckman, O.C., O. Kaarstad, O.H. Lie and I. Richards 1990. Agriculture and Fertilizers. Agricultural Group, Norsk Hydro, Oslo, Norway: CABI Publishing, Willingford, UK

Bolton, D.J., C.M. Byrne, J.J. Sheridan, D.A. McDowell and I.S Blair, 1999. The survival characteristics of a non-toxigenic strain of Escherichia coli O157:H7. J. Appl. Microbiol., 86: $407-411$

Boxall, A.B.A., H. Anthony, B. Sabine, B. Tatiana, B. Laura and D.F. Peter, 2009. Impacts of climate change on indirect human exposure to pathogens and chemicals from agriculture. Environ. Health Persp. 117: $508-514$

Bradford, S.A. and J.F. Schijven, 2002. Release of Cryptosporidium and Giardia from dairy calf manure: Impact of solution salinity. Environ. Sci. Technol., 36: 3916-3923

Breuer, T., D.H. Benkel, R.L. Shapiro, W.N. Hall, M.M. Winnett and M.J. Linn, 2001. A multistate outbreak of Escherichia coli $\mathrm{O} 157: \mathrm{H} 7$ infections linked to alfalfa sprouts grown from contaminated seeds. Emerg. Infect. Dis., 7: 977-982

Buchan, G.D. and M. Flury, 2004. Pathogen transport by water. In: Encyclopedia of Water Sciences. B.S. Stewart and T.A. Howell (eds.). Marcel Dekker, New York

Buck, A and J.D. Oliver, 2010. Survival of spinach-associated Helicobacter pylori in the viable but nonculturable state. Food Cont., 21: $1150-1154$

Chalmin, P. and C. Gaillochet, 2009. From waste to resource: an abstract of world waste survey. Available at: http://www.clairmab.com (Accessed: 20 June 2012)

Cole, D., L. Todd and S. Wing, 2000. Concentrated swine feeding operations and public health: A review of occupational and community health effects. Environ. Health Persp., 108: 699-685
Colwell, R.R., 2009. Viable but not cultivable bacteria. Microbiol. Monogr., 10: $121-129$

Costantini, V.P., A.C. Azevedo, L. Xin, M.C.Williams, J.F.C. Michel and L.J. Saif, 2007. Effects of Different Animal Waste Treatment Technologies on Detection and Viability of Porcine Enteric Viruses. Appl. Environ. Microbiol., 73: 5284-5291

Craggs, R.J., A. Zwart, J.W. Nagels and R.J. Davies-Colley, 2004. Modelling sunlight disinfection in a high rate pond. Ecol. Eng., 22: 113-122

Daverede, I.C., A.N. Kravchenko, R.G. Hoeft, E.D. Nafziger, D.G. Bullock, J.J. Warren and L.C. Gonzini, 2004. Phosphorus runoff from incorporated and surface-applied liquid swine manure and phosphorus fertilizer. J. Environ. Qual., 33: 1535-1544

Davis-Colley, R.J., A.M. Donnison, D.J. Speed, C.M. Ross and J.W. Nagels, 1999. Inactivation of faecal indicator microorganisms in waste stabilisation ponds: Interactions of environmental factors with sunlight. Water Res., 33: 1220-1230

DeVay, J.E. and J. Katan, 1991. Mechanisms of pathogen control in solarized soils. In: Soil Solarization, pp: 87-102. J. Katan and J.E. DeVay (eds.). CRC Press, Florida, USA

FAO (Food and Agriculture Organization), 2006. Livestock long shadow; environmental issues and options. Room, Italy, p. 408

Forslund, A., P. Finn, N.A. Mathias, M. Bo and D. Anders, 2011. Leaching of human pathogens in repacked soil lysimeters and contamination of potato tubers under subsurface drip irrigation in Denmark. Water Res., 45: 4367-4380

Gattie, D.K. and D.L. Lewis, 2004. A high-level disinfection standard for land-applied sewage sludges (Biosolids). Environ. Health Perspect. 112: $126-131$

Gerba, C.P. and J.E. Smith, 2005. Sources of pathogenic microorganisms and their fate during land application of wastes. J. Environ. Qual., 34: $42-48$

Guan, T.Y. and R.A. Holley, 2003. Pathogen survival in swine manure environments and transmission of human enteric illness-A review. $J$. Environ. Qual., 32: 383-392

Haapapuro, E.R., N.D. Barnard and M.J.D. Simon, 1997. Animal waste used as livestock feed: Dangers to human health. Prevent. Med., 26: 599-602

Harrison, E. and S.R. Oakes, 2002. Investigation of alleged health incidents associated with land application of sewage sludges. New Solut., 12 387-408

Harrus, S. and G. Baneth, 2005. Drivers for the emergence and reemergence of vector-borne protozoal and bacterial diseases. Int. J. Parasitol., 35: 1309-1318

Heinonen-Tanski, H. and J. Uusi-Kämppä, 2001. Runoff of faecal microorganisms and nutrients from perennial grass ley after application of slurry and mineral fertiliser. Water Sci. Technol., 43: 143-146

Henry, D.P., A.J. Frost, D. O'Boyle, R.D.A. Cameron, 1995. The isolation of salmonellas from piggery waste water after orthodox pondage treatment. Aust. Vet. J., 72: 478-479

Hutchison, M.L., A.K. Ashmore, K.M. Crookes, D.W. Wilson, S.J. Grives and B.T. Chambers, 2002. Enumeration of pathogens in livestock wastes and factors affecting their survival. In: Proceedings of the Joint CIWEM and Aqua Enviro Technology Transfer, pp: S3.15.1-S3.15.7. Hudson JP (eds.). Lowe. $7^{\text {th }}$ European Biosolids and Organic Residuals Conference. 17 to 20 November, 2002. Wakefield, Vol. 1. Wakefield, United Kingdom

Hutchison, M.L., L.D. Walters, A. Moore, K.M. Crookes and S.M. Avery, 2004. Effect of length of time before incorporation on survival of pathogenic bacteria present in livestock wastes applied to agricultural soil. Appl. Environ. Microbiol., 70: 111-5118

Hutchison, M.L., L.D. Walters, T. Moore, D.J.I. Thomas and S.M. Avery, 2005. Fate of Pathogens Present in Livestock Wastes Spread onto Fescue Plots. Appl. Environ. Microbiol., 71: 691-696

Ioannou, N. 2000. Soil solarization as a substitute for methyl bromide fumigation in greenhouse tomato production in Cyprus. Phytoparasitica, 28: 248-256

Jones, P.W., 1986. Sewage sludge as a vector of salmonellosis. In: Epidemiological Studies of Risks Associated with the Agricultural Use of Sewage Sludge, pp: 21-33. J.C. Block, A.H. Haielaar and P. L'Hermite (eds.). Elsevier, London 
Kelly, W.R., 1978. Animal and human health hazards associated with the utilization of animal effluents. In: A Workshop in the EEC Programme of Coordination of Research on Effluents. W.R. Kelly (eds.). November 21-23, Report of the European Communities. Dublin, Ireland

Khan, I.U.H., G. Vic, K. Rob, K. Wendell, R.L. David, M. Jim, N. Norman, P. Rob, R. Will, T. Edward, B. Eric van and A.E. Thomas, 2007. Development of a rapid quantitative PCR assay for direct detection and quantification of culturable and non-culturable Escherichia coli from agriculture watersheds. J. Microbiol. Meth., 69: 480-488

Kothary, M.H. and U. Babu, 2001. Infectious dose of foodborne pathogens in volunteers: A review. J. Food Saf., 21: 49-73

Kuczynska, E., D.J. Shelton and Y. Pachepsky, 2005. Effect of bovine manure on Cryptosporidium parvum oocyst attachment to soil. Appl. Environ. Microbiol., 71: 6394-6397

Kudva, I.T., K. Blanch and C.J. Hovde, 1998. Analysis of Escherichia coli O157:H7 survival in ovine or bovine manure and manure slurry. $J$. Appl. Environ. Microbiol., 64: 3166-3174

Lira-Saldivar, R.H., M.A. Salas, J. Cruz, A. Coronado, F.D. Hernández and E. Guerrero, 2004. Solarization and goat manure on weeds management and melon yield. Phyton, 73: 205-211

Makino, S.I., T. Kii, H. Asakura, T. Shirahata, T. Ikeda, K. Takeshi and K. Itoh, 2000. Does enterohaemorrhagic Escherichia coli O157 enter the VNC state in salmon roe? Appl. Environ. Microbiol., 66: 5536-5539

Marxsen, C.S., 2001. Potential world garbage and waste carbon sequestration. Environ. Sci. Policy, 4: 293-300

Mattick, K.L., F. Jorgensen, J.D. Legan, M.B. Cole, J. Porter, H.M. LappinScott and T.J. Humphrey, 2000. Survival and filamentation of Salmonella enterica serovar Enteritidis PT4 and Salmonella enterica serovar Typhimurium DT104 at low water activity. App. Environ. Microbiol., 66: 1274-1279

Mawdsley, J.L., R.D. Bardgett, R.J. Merry, B.F. Pain and M.K. Theodorou, 1995. Pathogens in livestock waste, their potential for movement through soil and environmental pollution. Appl. Soil Ecol., 2: 1-15

Mayo, A.W., 1995. Modelling coliform mortality in waste stabilisation ponds. J. Environ. Eng., 121: 140-152

Miyasaka, S.C., J.R. Hollyer and L.S. Kodani, 2001. Mulch and compost effects on yield and corm rots of taro. Field Crops Res., 71: 101-112

Mkhabela, M.S., A. Madania, R. Gordona, D. Burtonb, D. Cudmorea, A. Elmic and W. Hart, 2008 Gaseous and leaching nitrogen losses from no-tillage and conventional tillage systems following surface application of cattle manure. Soil Till. Res., 98: 187-199

Moss, L.H., E. Epstein and T.L. Logan, 2002. Evaluating Risks and Benefits of Soil Amendments used in Agriculture. Rep. 99-PUM-1. Water Environmental Research Foundation, Alexandria, Virginia, USA

Nicholson, F.A., B.J. Chambers, A.A. Moore, J.R. Nicholson and G. Hickman, 2004. Assessing and managing the risk of pathogen transfer from livestock manures into to the food chain. Water Environ. J., 18: 155-160

Nicholson, F.A., S.J. Groves and, B.J. Chambers, 2005. Pathogen survival during livestock manure storage and following land application. Bioresour. Technol., 96: 135-143

Niewolak, S., 1994. The sanitary and bacteriological estimation of surface and underground waters in the region of a pig slurry agricultural utilization. Pol. J. Environ. Stud., 3: 31-37

National Research Council (NRC), 2002. Biosolids Applied to Land: Advancing Standards and Practices. National Academy Press, Washington DC, USA

Olson, M.E., Goh, J., M. Philips, N. Guselle and T.A. McAllistr 1999. Giardia cyst and Cryptosporidium oocysts survival in water, soil and cattle faeces. J. Environ. Qual., 28: 1991-1996

Pachepsky, Y.A., A.M. Sadeghi, S.A. Bradford, D.R. Shelton, A.K Guber and T. Dao, 2006. Transport and fate of manure-borne pathogens: Modeling perspective. Agric. Water Manage., 86: $81-92$

Panutdaporn, N., K. Kawamoto, H. Asakura and S.I. Makino, 2006. Resuscitation of the viable but non-culturable state of Salmonella enterica serovar Oranienburg by recombinant resuscitationpromoting factor derived from Salmonella Typhimurium strain LT2 Int. J. Food Microbiol., 106: 241-247
Patz, J.A., T.K. Graczyk, N. Geller and A.Y. Vittor, 2000. Effects of environmental change on emerging parasitic diseases. Int. J. Parasitol., 30: 1395-1405

Pirchner, A., 2007. Betriebserfahrungen mit der UV-Desinfektion im Klärwerk Gut Marienhof, Vol. 1, pp: 47-49. DWA Landesverband Bayern Mitgliederrundbrief

Paez-Rubio, T., A. Ramarui, J. Sommer, H. Xin, J. Anderson and J. Peccia, 2007. Emission rates and characterization of aerosols produced during the spreading of dewatered Class B biosolids. Environ. Sci. Technol., 41: 3537-3544

Placha, I., J. Venglovsky, N. Sasakova and I. Svoboda, 2001. The effect of summer and winter seasons on the survival of Salmonella typhimurium and indicator microorganisms during the storage of solid fraction of pig slurry. J. Appl. Microbiol., 91: 1036-1043

Quintero-Betancourt, W., A.L. Gennaccaro, T.M. Scott and J.B. Rose, 2003. Assessment of methods for detection of infectious Cryptosporidium oocysts and Giardia cysts in reclaimed effluents. Appl. Environ. Microbiol., 69: 5380-5388

Quinton, J.N., S.F. Tyrrel and M.C. Ramos, 2003. The effect of incorporating slurries on the transport of faecal coliforms in overland flow. Soil Use Manage., 19: 185-186

Ramosa, M.C., J.N. Quintonb and S.F. Tyrrel 2006. Effects of cattle manure on erosion rates and runoff water pollution by faecal coliforms. $J$. Environ. Manage., 78: 97-101

Regueiras, A., M. Saker and V. Vasconcelos, 2009. Use of PCR for the early detection of pathogenic bacteria and Cyanobacteria in water samples from different urban water sources (Porto, Portugal) Fresen. Environ. Bull., 18: 2359-2365

Rezzonico, F., Y. Moënne-Loccoz and G. Défago, 2003. Effect of stress on the ability of a phlA-based quantitative competitive PCR assay to monitor biocontrol strain Pseudomonas fluorescens CHA0. Appl. Environ. Microbiol., 69: 686-690

Rosen, B.H., 2000. Waterborne Pathogens in Agricultural Watersheds, pp: 1-64. NRCS, Watershed Science Institute, School of Natural Resources, University of Vermont, Burlington, Vermont, USA

Schultz-Fademrecht, C., M. Wichern and H. Horn, 2008. The impact of sunlight on inactivation of indicator microorganisms both in river water and benthic biofilms. Water Res., 42: 4771-4779

Sheldrick, W., J.K. Syers and J. Lingard, 2003. Contribution of livestock excreta to nutrient balances. Nutr. Cycl. Agroecosys., 66: $119-131$

Shelton, D.R., Y.A. Pachepsky, A.M. Sadeghi, W.L. Stout, J.S. Karns and W.J. Gburek, 2003. Release rates of manure-borne coliform bacteria from data on leaching through stony soil. Vadose Zone J., 2: 34-39

Sidhu, J.P.S. and S.G. Toze, 2009. Human pathogens and their indicators in biosolids: A literature review. Environ. Int., 35: 187-201

Sinton, L.W., R.K. Finlay and P. Lynch, 1999. Sunlight inactivation of fecal bacteriophages and bacteria in sewage-polluted seawater. Appl. Environ. Microbiol., 65: 3605-3613

Skovgaard, N., 2007. New trends in emerging pathogens. Int. J. Food Microbiol., 120: 217-224

Smith, D., 2010. Sipping Cider Safely. Cooperative Extension Service. University of Wyoming, Laramie, Wyoming, US

Smith, K.A., A.J. Brewer, A. Dauven and D.W. Wilson, 2000. A survey of the production and use of animal manures in England and Wales. I Pig manure. Soil Use Manag., 16: 124-132

Smith, K.A., A.J. Brewer, A. Dauven and D.W. Wilson, 2001. A survey of the production and use of animal manures in England and Wales. III. Cattle manures. Soil Use Manage., 17: 77-87

Stapleton, J.J., 2000. Soil solarization in various agricultural production systems. Crop Prot., 19: 837-841

Strauch, D. and G. Ballarini, 1994. Hygienic aspects of the production and agricultural use of animal wastes. Zentralbl Vet. B, 41: 176-228

Streck, N.A., F.M. Schneider and G.A. Buriol, 1996. Soil heating by solarization inside plastic greenhouse in Santa Maria, Rio Grande do Sul, Brazil. Agric. For. Meteorol., 82: 73-82

Tanner, B.D., J.P. Brooks, C.N. Haas, C.P. Gerba and I.L. Pepper, 2005. Bioaerosol emission rate and plume characteristics during land application of liquid Class B biosolids. Environ. Sci. Technol., 39: $1584-1590$ 
US Environmental Protection Agency (US EPA), 1993. Standards for the use or disposal of sewage sludge; Final rules. 40 CFR Part 503 Subpart D. Fed. Regist. 58: 9398-9400. 1993. Available at: http://www.epa.state.oh.us/dsw/sludge/503_08_04_99.pdf. (Accessed: 20 Nov 2013)

US Environmental Protection Agency (US EPA), 1998. Environmental impacts of animal feeding operations. USEPA Office of Water, Standards and Applied Sci. Div., Washington DC, USA

US Environmental Protection Agency (US EPA), 1999. Control of Pathogens and Vector Attraction in Sewage Sludge. EPA/625/R92/013. Revised October 1999. United States Environmental Protection Agency, Office of Research and Development, National Risk Management Laboratory, Center for Environmental Research Information, Cincinnati, Ohio, USA

U.S. Environmental Protection Agency (US EPA), 2011. Problem Formulation for Human Health Risk Assessments of Pathogens in Land-applied Biosolids. National Center for Environmental Assessment, Cincinnati, OH. EPA/600/R-08/035F

United state department of Agriculture (USDA), 1992. National engineering handbook: Agricultural waste management field handbook. Part 651 (210-AWMFH, 4/92). Chapters 4 and 11. USDA Washington DC, USA

Uusi-Kämppä, J. and H. Heinonen-Tanskib, 2008. Evaluating slurry broadcasting and injection to ley for phosphorus losses and fecal microorganisms in surface Runoff. J. Environ. Qual., 37: 2339-2350

Varadyova, Z., I. Zelenak, P. Siroka and P. Dubinsky, 2001. In vitro fermentation of cellulosis amorphous and meadowhay in experimentally Ascaris suum infected lambs. Small Rumin. Res., 40: 155-164

Venglovsky, J., S. Nada and P. Iveta, 2009. Pathogens and antibiotic residues in animal manures and hygienic and ecological risks related to subsequent land application. Bioresour. Technol., 100: 5386-5391
Vernozy-Rozand, C. and S. Roze, 2003. Bilan des connaissances relatives aux Escherichia coli producteurs de Shiga-toxines (STEC). French Food Safety Agency, Maisons-Alfort (France). Available at: http://www.afssa.fr/Documents/MIC-Ra- STEC.pdf. (Accessed: 25 June 2013)

Webb, J., p. Brian, b. Shabtai and M. John, 2010. The impacts of manure application methods on emissions of ammonia, nitrous oxide and on crop response-A review. Agric. Ecosyst. Environ., 137: 39-46

World Health Organization (WHO), 2003. Emerging issues in water and infectious diseases. World health organization, Geneva. Available at: http://www.who.int/water_sanitation_health/emerging/en/. (Accessed: 2 Jan 2013)

Wichuk, K.M. and D. McCartney, 2007. A review of the effectiveness of current timetemperature regulations on pathogen inactivation during composting. J. Environ. Eng. Sci., 6: 573-586

Yukselen, M.A., B. Calli, O. Gokyay and A. Saatci, 2003. Inactivation of coliform bacteria in Black Sea waters due to solar radiation. Environ. Int., 29: 45-50

Zaleski, K.J., K.L. Josephson, C.P. Gerba and I.L. Pepper, 2005a. Potential regrowth and recolonization of salmonellae and indicators in biosolids and biosolid-amended soil. Appl. Environ. Microbiol., 71: 3701-3708

Zaleski, K.J., K.L. Josephson, C.P. Gerba and I.L. Pepper, 2005b. Survival, growth, and regrowth of enteric indicator and pathogenic bacteria in biosolids, compost, soil, and land applied biosolids. J. Residuals Sci. Technol., 2: 49-63

Zell, R., 2004. Global climate change and the emergence/re-emergence of infectious diseases. Int. J. Med. Microbiol., 293: 16-26

(Received 06 September 2014; Accepted 05 January 2015) 